Trinity University

Digital Commons @ Trinity

Modern Languages and Literatures Faculty

Research

Modern Languages and Literatures Department

2012

\title{
Material Ecocriticism: Dirt, Waste, Bodies, Food, and other Matter
}

Dana Phillips

Heather I. Sullivan

Trinity University, hsulliva@trinity.edu

Follow this and additional works at: https://digitalcommons.trinity.edu/mll_faculty

Part of the Modern Languages Commons, and the Modern Literature Commons

\section{Repository Citation}

Phillips, D. \& Sullivan, H.I. (2012). Material ecocriticism: Dirt, waste, bodies, food, and other matter. Interdisciplinary Studies in Literature and the Environment, 19(3), 445-447. doi:10.1093/isle/iss064

This Post-Print is brought to you for free and open access by the Modern Languages and Literatures Department at Digital Commons @ Trinity. It has been accepted for inclusion in Modern Languages and Literatures Faculty Research by an authorized administrator of Digital Commons @ Trinity. For more information, please contact jcostanz@trinity.edu. 
Introduction to Special Collection of essays for ISLE, summer 2012

"Material Ecocriticism: Dirt, Waste, Bodies, Food, and other Matter"

Edited and Introduced by Dana Phillips, Towson University; and Heather I. Sullivan, Trinity University

Chunks of walls and flooring crash in mangled heaps as an enormous orange crane smashes apart the science building. Fueled in part by oil money, Trinity University is updating its campus. Several hundred feet away, purple martins swoop down to feed squawking chicks nestled in white plastic gourds dangling from an angular metallic pole. In the university's community garden, ripe tomatoes are going to waste. Beyond the demolition site, a grackle lands on the neatly mown grass, where he puffs up and struts while other grackles watch him.

Which is the "healthier" sign: the Texas economy fueled by oil (and, increasingly, by fracking), the grackle's antics on a vast lawn in drought-ridden south-central Texas (though this lawn is irrigated with recycled water), the plastic bird houses filled to the brim with baby birds, or the flourishing little garden overflowing with neglected tomatoes in the summer heat (planted in the "natural" section of the campus's landscaping)? This collection of essays for ISLE assesses the material aspects of healthy economies, healthy environments, and healthy bodies, and it turns out that these things can and must be assessed in different ways. The tension between a healthy economy and a healthy environment is a familiar theme of environmentalist discourse. Yet as the contributors to this collection demonstrate, this dichotomy may not be rich enough to account for the concrete materiality of healthy and unhealthy bodies (however they are defined), both individually and en masse. For instance, we must explore the fact that having a very large number of healthy bodies in one species—human beings, for example—can be detrimental to healthy environments. At the same time, under the right conditions seemingly artificial environments like plastic martin houses and green lawns can be healthy or at least benign. Thus 
the determination of what is healthy, one of the main questions explored in Greg Garrard's essay, turns out to be quite complex. Instead of maintaining the dichotomy between economic and ecological "health," material ecocriticism adds a third piece to the discussion: the well-being of our material bodies_-both as agents and as small-scale, mobile environments in their own right.

The essays gathered here address the agency of material bodies participating in a broad spectrum of relationships with other forms of agentic matter on many scales. The contributors raise the questions of who or what has agency, when and how does agency make a difference, and what does it mean for human agency that it is surrounded by "vibrant" matter? Serenella Iovino and Serpil Oppermann offer a theoretical introduction to the "new materialisms" and describe how these discourses enable us to speak and write of agency in terms of cultural practices, physical bodies, and matter in all its forms. Stacy Alaimo, Greg Garrard, and Heather Sullivan consider oceanic bodies; healthy, unhealthy, and queer bodies; and dirt or soil as complex bodies. Finally, Dana Phillips and Andy McMurry explore the interconnections of food, farming, and bodies on multiple scales, ranging from the radical individualism informing Thoreau's dietary philosophy to the public relations campaigns of today's globalized, industrialized agriculture. The essays all investigate diverse examples of agentic materiality through evolutionary time, across bodies (as in Alaimo's “trans-corporeality), and at vast differences in scale.

Above all, material ecocriticism insists that human beings are "actors" operating within material processes that include multitudes of other "actors," the majority of which are not human or, for that matter, conscious. One might say that the contemporary form of human agency emerges from our status as an overpopulating, creatively adaptive, and very mobile species (rather than directly from our "warm, wrinkled brains," as Andy McMurry notes). Accordingly, 
material ecocriticism seeks to avoid the break-it-and-fix-it mentality of some environmental rhetoric, a mentality informed by the assumption that human agents (knowingly or inadvertently) create ecological problems, but can readily solve all of them at will with the right technology. To embrace such "can-do" attitudes without allowing for the full spectrum of agency is to act blindly, as managers of national parks, wilderness areas, and wildlife refuges have learnedthough often only after considerable cost of time and effort, and grievous mistakes. The fires that scorched Yellowstone two decades ago come to mind. But spectrums of agency come into play both locally and globally.

The focus of this ISLE collection on the agency of messy matter is for the most part radically local: it addresses the ecosystems on your skin, under your shoes, in your digestive tract, and in your very cells, too. In this way, the essays are able to entertain questions about matters both savory and unsavory, both appetizing and disgusting, in the conviction that all kinds of matter must fall within the purview of the environmental, the ecological, and the ecocritical. Hence, the essays move beyond questions of aesthetics, and raise questions about form and value that call for interdisciplinary answers.

While attending to the radically local, material ecocriticism also looks more broadly at human beings and the impact of their agency as an especially widely distributed species. Being a species means being material bodies with long-term histories, most of which are natural but some of which are decidedly unnatural. Nevertheless, our capacity for storytelling and toolmaking serves to extend our material bodies and the material processes in which they are entrained, not to sever us from them. We extend our material lives and bodies, and thereby we also extend and increase our material impact—which is to say we have never been immaterial since we first appeared on Earth, and will always be material so long as we remain here. 
Moreover, removing ourselves to Newt Gingrich's moon colony, or downloading ourselves onto a hard drive, will not mark a new and more visionary phase of our natural history. We will always be material beings living in a material world of one kind and/or another.

Material ecocriticism's emphasis on our storied bodies, and on the agentic capacities of matter, reveals the necessity of employing multiple scales when we think about our world. At the same time, it may help us to recognize that we live in multiple worlds, some of them of our own making but many of them not. So while material ecocriticism greatly expands our purview, it also has the bracing effect inherent to all cautionary tales. 